\title{
KEWENANGAN PENGELOLAAN, PENINGKATAN ANGGARAN DAN PERLUASAN STRUKTUR ORGANISASI PENDIDIKAN MADRASAH
}

\author{
MANAGEMENT AUTHORITY, INCREASE OF BUDGET \\ AND EXPANSION OF ORGANIZATIONAL STRUCTURE \\ OF MADRASAH
}

\author{
Nurudin \\ Pusat Penelitian dan Pengembangan Pendidikan Agama dan Keagamaan, \\ Balitbang dan Diklat Kementerian Agama Republik Indonesia \\ Jln. M.H. Thamrin 6 Jakarta, Email: dklaros@yahoo.com
}

\begin{abstract}
This paper examines various perspectives on the management of madrasah education that include: Firstly, what is the government's perspective on the management option of madrasah, is it the government's authority (the Ministry of Religion) or madrasah management option is the authority of local government? Second, Why does the financing of madrasah require increasing portion of the budget that is equivalent to ordinary schools? Third, why do we need improvement and expansion of authority for the managerial organizational structure in the Ministry of religion from the level of directorate to be directorate general level ?. The results of the study are first, the managerial authority of madrasah in the perspective of public administration shows that the management of madrasah is the domain of the government and has been delegated by the government to the Ministry of Religion. Second, the budget implementation for madrasah has not met twenty percent of the State Budget $(A P B N)$ as well as from the Regional Budget (APBD) as mandated by the constitution. This non-proportional budgeting has impacted the implementation of madrasah to be non-optimal. Third, the management organization of madrasah education in the Ministry of Religion is not optimal in serving the organization of madrasah. Increased authority and expansion of madrasah education management organization structure is an urgent need in order to balance the scope of development and organizational capacity.
\end{abstract}

Key Words: Madrasah, Management, Organization, Structure, Budget

\begin{abstract}
Abstrak
Tulisan ini mengkaji berbagai perspektif tentang pengelolaan pendidikan madrasah meliputi: Pertama Bagaimana perspektif administrasi pemerintahan terhadap pilihan pengelolaan madrasah sebagai kewenangan pemerintah (Kementerian Agama) ataupun pilihan pengelolaan madrasah sebagai kewenangan pemerintah daerah? Kedua, Mengapa pembiayaan madrasah membutuhkan peningkatan porsi anggaran yang setara dengan sekolah? Ketiga, Mengapa dibutuhkan peningkatan kewenangan dan perluasan struktur organisasi pengelola madrasah di Kementerian agama dari level direktorat menjadi direktorat jenderal?. Hasil kajian adalah, Pertama, Kewenangan pengelolaan pendidikan madrasah dalam perspektif administrasi pemerintahan menunjukkan, bahwa pengelolaan pendidikan madrasah merupakan domain pemerintah dan secara delegatif telah diberikan oleh pemerintah kepada Kementerian Agama. Kedua, Anggaran penyelenggaraan pendidikan madrasah belum memenuhi dua puluh persen dari Anggaran Pendapatan dan Belanja Negara (APBN) serta dari Anggaran Pendapatan dan Belanja Daerah (APBD) sebagaimana dimandatkan konstitusi. Penganggaran yang belum proporsional ini telah berdampak terhadap penyelenggaraan madrasah yang tidak optimal. Ketiga, Organisasi pengelola pendidikan madrasah di lingkungan Kementerian Agama belum optimal dalam melayani penyelenggaraan pendidikan madrasah. Peningkatan wewenang dan perluasan struktur organisasi pengelola pendidikan madrasah merupakan kebutuhan mendesak dalam rangka menyeimbangkan antara ruang lingkup pembinaan dan kapasitas organisasi.
\end{abstract}

Kata Kunci: Madrasah, Pengelolaan, Organisasi, Struktur, Anggaran 


\section{PENDAHULUAN}

Hadirnya madrasah sebagai satuan pendidikan formal dalam binaan Menteri Agama yang menyelenggarakan pendidikan umum dengan kekhasan agama Islam ${ }^{1}$, selain segaris dengan tujuan pendidikan nasional, sejatinya telah menjadi jawaban bagi penguatan keimanan, ketakwaan dan pembangunan moralitas peserta didik. Hal inilah yang membedakan substansi pembelajaran di madrasah dengan sekolah. Di sekolah terdapat satu mata pelajaran pendidikan agama, sementara madrasah mempunyai empat mata pelajaran pendidikan agama Islam: Aqidah Akhlak, AlQur'an Hadits, Sejarah Kebudayaan Islam dan Fikih.

Meski demikian, UU Nomor 20/2003 tentang Sisdiknas menyejajarkan madrasah dengan sekolah umum, dalam posisinya sebagai pendidikan formal. Akan tetapi, kesejajaran status dan posisi madrasah dengan sekolah pada bidang pendidikan di UU Sisdiknas tidak sertamerta meniscayakan pengelolaan urusan madrasah untuk diotonomikan. Sebaliknya Madrasah masih tetap menjadi bagian dari kewenangan pemerintah yang dikelola oleh kementerian agama sebagai instansi vertikal, mengingat madrasah merupakan bidang pendidikan Islam sebagai bagian dari kewenangan kementerian agama. Sementara kewenangan penyelenggaraan yang terkait dengan agama adalah urusan absolut yang harus dikelola secara vertikal oleh pemerintah, dalam hal ini oleh Kemen-

1 Peraturan Pemerintah Nomor 66 Tahun 2010 Tentang Pengelolaan dan Penyelenggaraan Pendidikan dan Peraturan Menteri Agama Nomor 90 Tahun 2013 Tentang Penyelenggaraan Pendidikan Madrasah. terian Agama, sebagaimana UU No 23/2014 tentang pemerintahan daerah.

Orientasi pembangunan nilai keagamaan (keislaman) pada pendidikan madrasah inilah yang menjadi satu latar belakang kondisi existing pengelolaan madrasah di bawah naungan Kementerian agama, yang hingga saat ini telah berkembang pesat meski di aspek anggaran masih mengalami kesenjangan dan ketimpangan dengan sekolah. Original intent (maksud asli) penyejajaran madrasah dengan sekolah dalam UU Sisdiknas tersebut sesungguhnya adalah untuk memberikan hak pelayanan yang sama antara sekolah dan madrasah, bukan karena urusan alokasi kewenangan.

Beberapa waktu terakhir muncul pemikiran untuk melimpahkan pengelolaan pendidikan madrasah dalam konteks kewenangan yang didesentralisasi (diotonomikan) sebagaimana pendidikan sekolah yang di kelola pemerintah daerah. Pemikiran semacam ini memang patut diapresiasi, namun musti sekaligus dikritisi dan dikaji lebih mendalam dampaknya didomain sosial, budaya dan agama. Jangan sampai otonomi pendidikan madrasah justru akan semakin mengikis nilai keagamaan (keislaman) sebagai ciri khas madrasah, hanya semata mata demi alasan administratif-prosedural belaka. Sebab permasalahan administratif prosedural dapat dijawab melalui realokasi anggaran yang dibarengi dengan peningkatan kewenangan dan perluasan struktur pengelola pendidikan madrasah (Kementerian Agama).

Pada konteks inilah, mengkaji madrasah dari berbagai perspektif untuk memberikan gambaran utuh agar pilihanpilihan yang akan diambil oleh negara 
dapat terukur manfaat dan madharatnya bagi masyarakat, umat Islam dan bangsa Indonesia secara keseluruhan, baik untuk mempertahankan madrasah sebagai urusan pemerintah ataupun untuk menggeser madrasah sebagai urusan pemerintah daerah. Permasalahan secara khusus adalah: Pertama, Bagaimana perspektif administrasi pemerintahan terhadap pilihan pengelolaan madrasah sebagai kewenangan pemerintah (Kementerian Agama) ataupun pilihan pengelolaan madrasah sebagai kewenangan pemerintah daerah? Kedua, Mengapa pembiayaan madrasah membutuhkan peningkatan porsi anggaran yang setara dengan sekolah? Ketiga, Mengapa dibutuhkan peningkatan kewenangan dan perluasan struktur organisasi pengelola madrasah di kementerian agama dari level direktorat menjadi direktorat jenderal?

\section{Perspektif Hasil-Hasil Penelitian Terhadap Kondisi Madrasah}

Berbagai penelitian tentang eksistensi madrasah yang berkaitan erat dengan konteks kewenangan pengelolaan madrasah secara umum. Dan pada bab selanjutnya (analisis), beragam penelitian ini menjadi fakta empiris terhadap pengelolaan madrasah, peningkatan anggaran dan perluasan struktur pengelola madrasah. Penelitian tersebut antara lain:

Pertama, Respons Masyarakat terhadap Jati diri Madrasah, Tahun 2007. Penelitian ini mengkaji dua permasalahan, yakni (1) bagaimana respons masyarakat terhadap jati diri dan kekhasan madrasah. (2) bagaimana respons masyarakat terhadap reposisi madrasah sebagai pendidikan umum menurut UU Sisdiknas Nomor 20
Tahun 2003. Survei dilakukan di 16 daerah kabupaten/kota terpilih yang tersebar di 8 (delapan) Provinsi, yakni Nangroe Aceh Darussalam (Aceh Besar dan Pidie, Jambi (Batanghari dan Tanjung-Jabung Barat), Banten (Pandeglang dan Serang), Jawa Barat (Bandung dan Kota Bandung), Jawa Tengah (Magelang dan Purwokerto), Jawa Timur (Malang dan Jombang), Kalimantan Selatan (Hulu Sungai Utara dan Banjar), Sulawesi Selatan (Gowa dan Bone). Hasil penelitian dapat disimpulkan bahwa: (1) masyarakat memberikan respons yang sangat tinggi terhadap pentingnya jati diri madrasah sebagai lembaga pendidikan islam. Masyarakat menyatakan bahwa madrasah tidak mungkin dipisahkan dari momentum religiusitas dan dinamika sosial politik yang menyertai kelahirannya. Pendeknya, upaya pengembangan madrasah tidak dapat dilepaskan dari aspek kesejarahan madrasah itu sendiri. Sebab jika itu terjadi, hanya akan memperlebar ruang disparitas kebutuhan terhadap jenis pendidikan antara pemerintah dengan masyarakat, dan pada gilirannya memosisikan pendidikan madrasah terasing dari lingkungannya. Pada ranah lebih praksis, sistem pendidikan madrasah yang tetap konsen pada pendalaman ajaran agama (tafaqquh fid-din) masih tetap menjadi kebutuhan masyarakat dan mewakili kepentingan jatidiri sebuah lembaga pendidikan Islam, bahkan mandat basic dalam bidang ilmu agama itu harus lebih dikukuhkan dan diupayakan sejajar dengan lembaga sekolah dari berbagai aspek kependidikannya. Dengan demikian, ilmu ilmu agama yang menjadi spesialisasi madrasah-meski ke depan diharapkan bukan satu satunya-tidak menjadi periferal vis a vis lembaga pendidikan sekolah. 
Madrasah adalah madrasah; sebagai lembaga pendidikan islam ia telah menjadi trademark yang distingtif dan memiliki nilai historis dan politisnya sendiri, yang tidak bisa begitu saja dikesampingkan apalagi jati diri madrasah yang demikian itu benar- benar dibutuhkan oleh masyarakat pendukungnya. (2) sebagaimana halnya respons masyarakat terhadap jari diri madrasah, respons masyarakat terhadap karakteristik madrasah berbasis masyarakat, maka isi pendidikan di madrasah idealnya adalah nilai kultural yang tetap hidup dan dikembangkan oleh masyarakat itu sendiri. Karena itu, kurikulum madrasah harus mengakomodir secara memadai materi materi ilmu agama sebagai penjabaran dari visi, misi, dan tujuan diselenggarakannya madrasah, bahkan sesuai dengan tujuan pendidikan nasional. Penting pula bagi pemerintah untuk menghormati sikap independen masyarakat yang membina madrasah swasta, namun pemerintah harus tetap menjadi fasilitator yang baik dalam pengembangan madrasah. Varian masyarakat dalam mengelola madrasah pun masih tetap relevan dengan manajemen pendidikan saat ini, dilihat dari sudut pandang adanya kemampuan mereka secara otonom dan mandiri.

Kedua, Studi Pembiayaan Pendidikan Madrasah, tahun 2011. Penelitian ini menggunakan pendekatan kuantitatif, mengkaji beberapa permasalahan yakni: (1) Apa saja yang menjadi komponen pembiayaan pendidikan pada madrasah. (2) Seberapa besar satuan biaya yang dibutuhkan dalam pengelolaan pendidikan per siswa berdasarkan varian peringkat akreditasi madrasahA, B, C dan TT (TidakTerakreditasi). Berdasarkan kajian pembiayaan pendidikan di madrasah sasaran, secara garis besar dapat disimpulkan: Apabila wacana pendidikan gratis di madrasah akan diimplementasikan, maka Kementerian Agama RI harus menyiapkan dana tambahan untuk pembiayaan kebutuhan dasar pembelajaran di madrasah, mengingat dana BOS yang tersalurkan selama ini, berdasarkan perhitungan dalam penelitian ini, barumeng-cover sebagian darikebutuhan tersebut. Adapun rinciannya adalah: (1) Pembiayaan pendidikan di madrasah perlu memperhatikan tiga paket pembiayaan, yaitu: paket pembiayaan kebutuhan dasar pembelajaran (operasional), meliputi dana personalia dan dana nonpersonalia; paket pembiayaan investasi yang berupa sarana prasarana, pengembangan SDM dan modal tetap; dan paket pembiayaan khusus seperti percepatan peningkatan mutu atau pengembangan kekhasan tertentu. (2) Dana BOS yang sejauh ini jadi andalan pembiayaan pendidikan di madrasah, ternyata dari perhitungan penelitian ini baru meng-cover sebagian kebutuhan pembiayaan dasar pembelajaran, yaitu sekitar $62,57 \%$. Dan perlu digaris bawahi bahwa dana tersebut masih sebatas mengcover biaya operasional satuan pendidikan. Kehadiran Dana Bantuan Operasional Sekolah (BOS) telah berkontribusi dalam meng-cover biaya pendidikan di madrasah. Dari rata-rata madrasah yang diteliti, dana BOS untuk madrasah swasta berkontribusi meng-cover $70 \%$ dari kebutuhan pembiayaan pendidikan di satuan madrasah swasta; sedangkan di madrasah negeri dana BOS telah berkontribusi sebanyak 30\% dari anggaran pendidikan. (3) Pada jenjang Madrasah Ibtidaiyah (MI), tingkatan akreditasi nampaknya tidak menentukan 
secara beraturan kebutuhan rata-rata unit cost siswa. Data lapangan menunjukkan cost tertinggi terjadi justru di MI terakreditasi B. Secara berurutan dapat disebutkan rata-rata unit cost berdasarkan akreditasi madrasah. Pada madrasah A (unit cost rata-rata Rp. 168.798) , pada madrasah akreditasi B (Rp. 219.903), madrasah terakreditasi C (Rp. 80.810), dan madrasah tidak terakreditasi/ TT (Rp. 144.576). (4) Pada jenjang Madrasah Tsanawiyah (MTs), tingkatan akreditasi membutuhkan pembiayaan yang berbeda. Pada MTs terakreditasi A rata-rata unit cost diperlukan paling tinggi dibandingkan tingkatan akreditasi lainnya. Secara berurutan pada madrasah terakreditasi A (Rp. 353.461,-); madrasah terakreditasi B (Rp. 202.515,-), Madrasah terakreditasi C (Rp. 53.598,-) dan justru pada pada Madrasah Tidak Terakreditasi/TT rata-ratanya agak naik sedikit dibandingkan akreditasi C, yaitu Rp. 61.033,-. (5) Pada jenjang Madrasah Aliyah (MA), tingkatan akreditasi menunjukkan gradasi yang beraturan. Pada akreditasi A (Rp. 596.433,-), pada MA terakreditasi B (Rp. 138.209,-), pada madrasah terakreditasi C (Rp. 77.233,-) dan pada MA tidak terakreditasi/TT (Rp. 54.783). (6) Penggunaan dana BOS pada tingkat satuan madrasah antara madrasah satu dengan madrasah yang lain mempunyai persentase alokasi yang bervariasi. Peta distribusi itu sangat ditentukan oleh situasi dan kondisi satuan madrasah yang mengoperasikannya. Tren umum pada madrasah swasta, alokasi terbesar terletak pada item honor/gaji pendidik dan tenaga kependidikan. Sementara pada madrasah negeri, sekalipun dalam jumlah yang tidak sama, masih tetap juga menggunakan dana BOS sebagai tambahan kesejahteraan guru.
Ketiga, Keberhasilan Pembelajaran Pendidikan Agama Islam di Madrasah, tahun 2012. Penelitian menggunakan metode kuantitatif, untuk menjawab beberapa permasalahan sebagai berikut:(1) bagaimana tingkat keberhasilan pembelajaran PAI di Madrasah Aliyah (MA) yang diukur dengan nilai akhir semester setiap mata pelajaran PAI, sikap dan perilaku sosial-keagamaan yang diturunkan dari materi pelajaran PAI. (2) apakah proses pendidikan, tepatnya aktivitas pembelajaran mata pelajaran agama Islam di ruang kelas oleh guru PAI berpengaruh secara signifikan terhadap pembentukan sikap (karakter) dan perilaku sosial-keagamaan siswa. (3) apakah faktor faktor nonkependidikan formal, tepatnya pola asuh sosial-keagamaan orangtua di keluarga, mempengaruhi keberhasilan pembelajaran PAI siswa MA. Penelitian dilakukan di 16 provinsi: Nangroe Aceh Darussalam, Sumatera Utara, Sumatera Barat, Riau, Lampung, DKI Jakarta, Jawa Barat, Jawa Tengah, Jawa Tmur, Bali, Nusa Tenggara Barat, Kalimantan Barat, Kalimantan Selatan, Sulawesi Tengah, Sulawesi Selatan, dan Maluku.

Secara keseluruhan dapat disimpulkan (1) hasil capaian kognitif siswa MA dalam pembelajaran PAI relatif sudah cukup baik. Rata rata nilai untuk seluruh mata pelajaran selalu di atas 78 poin dari score maksimal 100. Namun demikian, masih ada sejumlah siswa dengan capaian di bawah standar kelulusan. (2) hasil capaian kognitif ini sangat bervariasi menurut latar belakang asal MA siswa. Variabel status negeriswasta MA, dan tingkat akreditasi terbukti berpengaruh secara signifikan terhadap hasil capaian kognitif siswa untuk bidang pelajaran PAI. Nilai siswa MAN dan MA yang 
terakreditasi memperlihatkan hasil capaian kognitif yang tinggi. (3) capaian afektif siswa pada pelajaran PAI memperlihatkan fenomena menarik. Salah satu tujuan utama pembelajaran PAI adalah penanaman nilainilai luhur agama seperti menghargai perbedaan, menjaga kesantunan dan bersikap ramah dan inklusif pada orang yang berbeda agama.

Hasil penelitian ini menunjukkan, capaian afektif pada bidang-bidang penanaman nilai luhur dalam kehidupan relasi lintas agama dalam konteks bermasyarakat, berbangsa dan bernegara mendapatkan perhatian yang memadai. Di sini, apresiasi terhadap nilai nilai etis teologis, juga sosial relasi lintas agama masih sangat perlu mendapat pembinaan intensif. Tingkat penolakan atau resistensi terhadap interaksi dengan umat yang berbeda agama cukup tinggi.

Keempat, Studi Kebutuhan Akreditasi Madrasah, tahun 2013. Survei dilaksanakan di 27 Kabupaten dan kota pada 9 (sembilan) provinsi, yakni: Sumatera Utara, Lampung, Riau, Banten, Jawa Barat, Jawa Tengah, Jawa Timur, Sulawesi Selatan, dan NTB. Penelitian ini mengajukan 10 pertanyaan, yakni: (1) kenapa masih banyak madrasah yang belum terakreditasi; (2) mengapa masih banyak madrasah terakreditasi masih di bawah standar minimal yang dirumuskan dalam Renstra Pendidikan Islam (2010-2014); (3) apa saja kebutuhan madrasah yang belum dimiliki untuk mencapai kategori akreditasi A; (4) faktor apa saja yang menghambat madrasah untuk mencapai kategori akreditasi A; (5) bagaimana pemahaman dan peran kepala madrasah dalam akreditasi; (6) bagaimana peran kementerian agama di tingkat kabupaten/kota, provinsi dan pusat dalam proses akreditasi madrasah; (7) bagaimana kontribusi pemerintah daerah untuk memenuhi kebutuhan akreditasi madrasah; (8) bagaimana kondisi mutu penyelenggaraan pendidikan antara madrasah yang sudah terakreditasi dengan yang belum terakreditasi; (9) bagaimana mutu lulusan pendidikan antara madrasah terakreditasi dengan yang belum terakreditasi; (10) apa upaya yang dapat dilakukan pihak pihak terkait untuk memenuhi kebutuhan akreditasi.

Hasil penelitian sebagai berikut: (1) Masih adanya madrasah yang belum terakreditasi disebabkan oleh: (a) pernah mengajukan tapi belum kebagian kuota, (b) lokasi madrasah terpencil sehingga kurang akses, (c) sudah pernah terakreditasi namun belum mengajukan lagi karena belum mendapatkan kuota, (d) belum pernah mengajukan akreditasi dan kepala madrasah tidak mengetahui cara pengajuan akreditasi. (2) Masih banyak jenjang madrasah terakreditasi berada di bawah standar minimal (terakreditasi B) sesuai rumusan Renstra Pendis (2010-2014), hal ini dikarenakan sumber pembiayaan operasional madrasah swasta hanya mengandalkan dari yayasan, sehingga banyak sarana belum memadai (hanya sekedar ada). (3) Kebutuhan-kebutuhan madrasah yang belum dimiliki untuk mencapai kategori akreditasi A pada semua jenjang Madrasah Ibtidaiyah (MI), madrasah Tsanawiyah (MTs) dan Madrasah Aliyah (MA) di antaranya: pertama, standar isi, perlu perbaikan pengembangan kurikulum, persiapan kalender akademik, program pengembangan diri siswa. Kedua, standar proses, madrasah harus memperbaiki kemampuan guru dalam pengembangan KTSP, silabus, dan sistem 
evaluasi, supervisi dan pengawasan. Ketiga, standar kelulusan, perlu peningkatan keterampilan siswa dalam pengalaman belajar yang kritis, logis dan pengembangan IPTEK. Keempat, standar pendidik dan tenaga kependidikan, perlu peningkatan ketersediaan pendidik, tenaga perpustakaan, tenaga laboratorium yang sesuai dengan latar belakang. Kelima, standar sarana, perlu kesiapan ruang laboratorium, perpustakaan, ruang konseling, UKS. Keenam, standar pengelolaan, terkait dengan kesiapan struktur organisasi yang jelas dan pengelolaan pembiayaan yang rapi dan penggunaan administrasi melalui sistem informasi manajemen.

Ketujuh, standar pembiayaan, perlu kesiapan pembukuan biaya operasional, melakukan sistem subsidi silang bagi siswa yang kurang mampu dan pengelolaan biaya personal yang akuntabel dan transparan. Kedelapan, standar penilaian, perlu perbaikan seputar pengolahan hasil penilaian, pengembangan instrumen penilaian, penentuan kriteria kenaikan kelas dan pelaporan hasil penilaian setiap akhir semester. (4) Pengawas berperan dalam proses pengajuan akreditasi di madrasah binaan walau masih ada beberapa pengawas yang tidak dilibatkan. Bagi pengawas yang dilibatkan dalam proses akreditasi, kegiatannya dalam bentuk: (a) pengawas diajak berkonsultasi dengan madrasah yang akan diakreditasi, (b) keikutsertaan pengawas mulai dari penyiapan, permohonan, pembinaan akreditasi, (c) pengawas diminta pertimbangannya dalam penentuan madrasah mana yang layak diajukan untuk akreditasi. Berkaitan dengan pembinaan yang dilakukan pengawas dalam proses akreditasi madrasah dilakukan melalui: (a) program pembinaan dalam rangka peningkatan kualitas berupa program tahunan dan prasarana kegiatan belajar mengajar, (b) pelatihan pembuatan kurikulum dan pembinaan secara langsung terkait delapan Standar Nasional Pendidikan (SNP), (c) mereview KTSP dan penyusunan dokumen. (5) proses peningkatan mutu penyelenggaraan pendidikan madrasah dapat dilihat dari sejauhmana pencapaian pemenuhan delapan SNP. (6) Berkaitan dengan pencapaian SNP, pada jenjang madrasah yang belum terakreditasi menunjukkan sebagai berikut: (a) jenjang MI pada umumnya pada standar sarana prasarana berada pada kategori kurang, standar pembiayaan kategori cukup, standar penilaian kategori cukup, standar pendidik dan tenaga kependidikan kategori cukup, standar kelulusan kategori cukup, standar pengelolaan kategori cukup, standar proses kategori baik, dan standar isi juga berkategori baik. (b) jenjang MTs secara umum standar sarana prasarana kategori cukup, standar pembiayaan kategori cukup, standar penilaian kategori cukup, standar pendidik dan tenaga kependidikan kategori baik, standar kelulusan kategori baik, standar pengelolaan kategori baik, standar proses kategori baik, dan standar isi juga berkategori baik. (c) Jenjang MA pada umumnya standar sarana prasarana berada pada kategori kurang, standar pembiayaan kategori baik, standar penilaian kategori baik, standar pendidik dan tenaga kependidikan kategori baik, standar kelulusan kategori baik, standar pengelolaan kategori cukup, standar proses kategori baik, dan standar isi juga berkategori baik. (7) Beberapa aspek yang yang belum terpenuhi pada jenjang MI yang belum terakreditasi antara lain: (a) kesiapan 
guru dalam membuat silabus secara mandiri mencapai 23,3\%, (b) pemberian keterampilan/karya siswa dalam membaca, menulis, dalam bahasa Indonesia dan Inggris 53,5\%, (c) ketersediaan tenaga administrasi dan tenaga perpustakaan dan ketersediaan laboratorium IPA hanya 9,3\%, (d) ketersediaan kepemilikan sistem informasi manajemen untuk mendukung administrasi hanya sebesar 39,5\%, (e) hanya 27,6\% madrasah yang melakukan subsidi silang terhadap orang tua yang tidak mampu, (f) masih ada 25,6\% madrasah yang tidak melaporkan pencapaian hasil belajar siswa kepada Dinas Pendidikan atau Kanwil Kemenag. (8) Beberapa aspek yang belum terpenuhi pada jenjang MTs yang belum terakreditasi antara lain: (a) kesiapan guru menyusun silabus secara mandiri mencapai 76,7\% madrasah, (b) terdapat 50\% madrasah melakukan KBM dari berbagai sumber belajar, (c) masih ada 43,3\% madrasah tidak memiliki kualifikasi kepala laboratorium yang sesuai dengan kriteria standar minimal, (d) madrasah memiliki laboratorium IPA sekitar 60\%, dan minimnya ketersediaan ruang konseling, ruang usaha kesehatan, dan ruang kesiswaan, (e) pelibatan masyarakat dalam pengelolaan pendidikan madrasah sejumlah 23,3\% dan masih sedikitnya kepemilikan sistem informasi manajemen untuk mendukung administrasi pendidikan. (f) sejumlah 30\% madrasah melaksanakan subsidi silang untuk membantu siswa kurang mampu, (g) sejumlah 73,3\% guru mengembangkan instrumen dan pedoman penilaian sesuai dengan bentuk dan teknik penilaian. (9) Beberapa aspek yang belum terpenuhi pada jenjang MA yang belum terakreditasi antara lain: (a) hanya $36,8 \%$ madrasah dalam pembuatan kurikulum muatan lokal melibatkan guru, komite madrasah, dan instansi terkait, (b) guru melakukan pengembangan silabus dilakukan secara mandiri dalam setiap kelompok mata pelajaran sekitar 52,6\% madrasah dan masih sedikit kepala madrasah melakukan supervisi proses pembelajaran dengan cara pemberian contoh, diskusi, pelatihan dan konsultasi, (c) sejumlah $36,8 \%$ madrasah yang memberikan penghargaan pada siswa berprestasi, (d) hanya sejumlah 26,3\% madrasah yang memiliki tenaga perpustakaan minimal kualifikasinya Diploma satu (D1) dan tenaga laboratorium yang memenuhi kualifikasi Diploma satu (D1) masih sedikit, (e) madrasah yang tidak memiliki ruang laboratorium kimia mencapai $73,7 \%$ dan masih sedikit yang memiliki ruang laboratorium biologi dan bahasa, (f) belum semua madrasah memiliki ruang konseling, dan ruang UKS, (g) hanya 42,1\% madrasah memiliki sistem informasi manajemen untuk mendukung administrasi pendidikan dan masih sedikit madrasah melibatkan masyarakat dan membangun kemitraan dengan lembaga lain yang relevan dalam pengelolaan pendidikan, (h) pelaksanaan subsidi silang untuk membantu siswa kurang mampu mencapai 47,49\% madrasah, (i) hanya 57,9\% madrasah yang menyelenggarakan ujian madrasah dan menentukan kelulusan siswa sesuai dengan kriteria yang berlaku. (10) Strategi yang harus dilakukan terkait pemenuhan kebutuhan akreditasi di antaranya: (-) Bagi madrasah yang belum terakreditasi: (a) pengawas selalu menyampaikan kepada lembaga madrasah terkait pentingnya akreditasi dan kepala madrasah perlu memahami materi akreditasi, (b) pengawas mengadakan bimbingan teknis untuk 
menjawab setiap instrumen, (c) pembinaan dan pendampingan dalam penataan pemenuhan delapan SNP, (d) mendorong kepala madrasah agar selalu meningkatkan kapasitas madrasah. (-) Bagi madrasah yang sudah terakreditasi $C$ di antaranya: (a) melakukan peningkatan yang bersifat pemberdayaan, (b) memberikan pembinaan yang intensif terhadap pihak yang terkait (kepala madrasah dan tim akreditasi madrasah), (c) madrasah lebih mempersiapkan diri untuk akreditasi yang akan datang, dan pihak terkait juga ikut memberikan perhatian, (d) melakukan evaluasi diri madrasah dengan melengkapi sarana dan prasarana yang belum memadai di madrasah, (e) pembinaan berkelanjutan. (-) Bagi madrasah yang terakreditasi B di antaranya: (a) melakukan pemantauan pemenuhan delapan SNP secara periodik oleh pengawas, (b) harus ada komitmen pihak terkait (kepala madrasah dan tim akreditasi madrasah), (c) memperbaiki dan melengkapi dokumen akreditasi yang mendapat nilai di bawah standar, (d) meningkatkan mutu tamatan dan kualitas pembelajaran, (e) pembinaan berkelanjutan. (-) Bagi madrasah yang sudah terakreditasi A di antaranya: (a) meningkatkan sarana prasarana madrasah baik secara kualitas dan kuantitas untuk kelancaran pelaksanaan pembelajaran dan berorientasi pada pencapaian SNP, (b) melakukan pembinaan yang lebih intensif terhadap pengelola madrasah terutama para guru menyangkut peningkatan pengetahuan dan keterampilan, melalui berbagai diklat tentang proses pembelajaran, kurikulum, penilaian dan teknis peningkatan kompetensi lulusan, (c) menghidupkan dan menggerakkan MGMP dengan memberikan bantuan pendanaan memadai yang berguna untuk melakukan berbagai kegiatan peningkatan pengetahuan dan keterampilan SDM, (d) memberikan anggaran yang memadai kepada madrasah guna melakukan berbagai kegiatan pengembangan SDM, guna peningkatan pelaksanaan proses pembelajaran, pengembangan kurikulum, penilaian dan meningkatkan kompetensi lulusan.

Kelima, Evaluasi Penegerian Madrasah, Tahun 2014. Penelitian ini menggunakan metode kuantitatif pada madrasah Negeri (MIN, MTsN, MAN) yang tersebar di 12 provinsi, yakni: Jawa Barat, Jawa Tengah, Daerah Istimewa Yogyakarta, Banten, Sumatera Selatan, Riau, Bangka Belitung, Lampung, Kalimantan Selatan, Sulawesi Utara dan Bali. Penelitian ini mengkaji 7 (tujuh) permasalahan, antara lain: (1)Apa motivasi yang melatarbelakangi penegerian madrasah, (2) siapa tokoh yang berperan mendasari munculnya kebijakan penegerian madrasah, (3) bagaimana dukungan masyarakat terhadap penegerian madrasah, (4) bagaimana perubahan pengelolaan madrasah setelah penegerian, (5) apakah dampak kebijakan penegerian terhadap mutu madrasah, (6) apa kendala dalam pengelolaan madrasah setelah dinegerikan, (7) bagaimana strategi peningkatan mutu madrasah.

Hasilnya dapat dirangkum sebagai berikut: (1) Motivasi yang melatarbelakangi penegerian madrasah di antaranya: untuk mendirikan lembaga pendidikan yang terjangkau masyarakat lemah (38,75\%), menyebarluaskan ilmu agama (28,8\%), ingin mendirikan lembaga yang berkualitas $(21,6 \%)$, pengabdian $(10,8 \%)$. Motivasi untuk mencari keuntungan tidak menjadi latar belakang masyarakat dalam menegerikan 
madrasah. (2) Tokoh berperan dalam proses penegerian madrasah di antaranya: Kemenag/Pemda (PNS), pegawai swasta, dan mubalig. (3) Dukungan masyarakat untuk persyaratan penegerian diberikan moril maupunmateriil,materidalambentuktenaga dan biaya, moril dalam bentuk dukungan doa dan perhatian. Bentuk dukungan lain adalah membentuk komite madrasah. Survei menunjukkan pembentukan komite madrasah dibentuk (64\%) oleh keterlibatan unsur yang lengkap: kepala madrasah, yayasan, orang tua, dan tokoh masyarakat. (4) Dari enam komponen pengelolaan pendidikan (perekrutan, manajemen, dukungan masyarakat, pendidik dan tenaga kependidikan, sarana prasarana, kesiswaan), telah terjadi perubahan nilai yang signifikan dari sebelum madrasah dinegerikan dan setelah dinegerikan. Perubahan terbesar terdapat pada komponen pendidik dan tenaga kependidikan dan komponen sarana prasarana. (5) Dampak kebijakan penegerian madrasah membawa pengaruh terhadap prestasi siswa dan tingginya animo masyarakat,(6) Kendala yang dihadapi dalam menyelenggarakan kegiatan pengelolaan madrasah setelah dinegerikan adalah kendala keterbatasan sarana prasarana, rendahnya anggaran dari pemerintah, dan kurangnya kompetensi guru. (7) Strategi pemerintah dalam meningkatkan mutu madrasah dapat dilakukan melalui perbaikan manajemen madrasah: manajemen kurikulum, kesiswaan, sarana prasarana, tenaga pendidik, hubungan masyarakat, keuangan dan tenaga kependidikan. Bidang manajemen membutuhkan perhatian, mulai perencanaan, pengorganisasian, pengaruh, pengendalian (evaluasi) serta aspek perilaku dan daya dukung manajemen yaitu SDM dan Iptek.

Keenam, Madrasah di daerah Marginal (Studi Penyelenggaraan Madrasah di Daerah Minoritas Keagamaan), tahun 2014. Penelitian dilakukan pada 10 daerah, menggunakan metode kualitatif, yakni di Kabupaten Manokwari Papua Barat, Kabupaten Sekadau Kalimantan Barat, Kabupaten Kupang, Nusa Tenggara Timur, Kabupaten Jembrana Bali, Kota Denpasar Bali, Kabupaten Sikka Nusa Tenggara Timur, Kabupaten Bitung Sulawesi Utara, Kota Manado Sulawesi Utara, Kota Ambon Maluku, dan Kabupaten Melawai Kalimantan Barat. Permasalahan yang diangkat dalam penelitian ini adalah mengenai bagaimana eksistensi penyelenggaraan madrasah di daerah minoritas keagamaan (minoritas muslim) dilihat dari (1) kondisi umum daerah sekitar madrasah, (2) sejarah berdirinya madrasah, (3) kondisi umum madrasah terkait komponen SNP, (4) kebijakan pemerintah, (5) relasi dan lingkungan sosial masyarakat sekitar madrasah, (6) faktor pendukung dan penghambat.

Hasil penelitian menunjukkan bahwa madrasah di daerah minoritas keagamaan mengalami permasalahan yang sama, yakni madrasah mengalami kondisi memprihatinkan, terkait dengan faktor minimnya afirmative action dari kebijakan pemerintah daerah di satu sisi. Pada saat yang sama, kurangnya penyediaan akses, fasilitas dan berbagai kebutuhan pembelajaran dan peningkatan mutu madrasah karena minimnya anggaran yang diberikan, sangat berpengaruh terhadap kondisi madrasah di daerah minoritas. 
Analisis Pengelolaan, Penganggaran dan Struktur Organisasi Pendidikan Madrasah

\section{Perspektif Administrasi Pemerintahan Terhadap Kewenangan Pengelolaan Pendidikan Madrasah}

Untuk mengurai problematika pengelolaan madrasah secara holistik dalam tata kelola administrasi pemerintahan, niscaya dikemukakan terlebih dahulu beragam Undang Undang (UU) sebagai regulasi pokok setelah konstitusi (UUD 1945) yang menjadi dasar bagi pengelolaan madrasah. Terutama kaitan tarik menarik antara posisi madrasah sebagai pendidikan yang melekat di dalamnya klausul 'agama' sebagai urusan absolut (vertikal) di satu sisi, dengan urusan konkuren (urusan yang didesentralisasikan) dalam klausul 'pendidikan' di sisi lainnya. Selanjutnya, akan diuraikan pula peraturan organik di bawah UU, agar didapatkan sebuah pemahaman menyeluruh tentang pola pengelolaan madrasah dalam konteks distribusi kewenangan pemerintahan. Hal ini penting dilakukan dalam rangka mendudukan secara jernih pengelolaan madrasah, tidak semata mata dalam perspektif administrasi-prosedural, namun yang terpenting adalah positioning madrasah dalam konteks pengelolaan administrasisubstantif yang niscaya berkesesuaian dengan prinsip-prinsip pembangunan mental-spiritual berbangsa dan beragama.

Pertama-tama merujuk pada konstruksi UU Nomor 20 Tahun 2003 tentang Sistem Pendidikan Nasional (UU Sisdiknas) dalam mengatur dan memosisikan madrasah. Pada UU ini terutama Pasal 17 Ayat 2 dan Pasal 18 Ayat 3, madrasah disederajatkan dengan sekolah (umum) dalam kategori pendidikan formal. Maknanya, tidak ada lagi perbedaan antara madrasah dan sekolah dalam segala aspeknya, baik aspek substansi (standar pendidikan dan kurikulumnya), aspek manajerial, dan terpenting aspek anggaran dan infrastruktur (fasilitas, saranaprasarana, pendanaan). Madrasah kini telah menjadi subsistem pendidikan nasional.

Bagi madrasah, sejatinya status yang diberikan oleh UU Sisdiknas tersebut ibarat pisau bermata dua, menjadi berkah sekaligus masalah. Status ini menjadi berkah dalam konteks modernisasi madrasah untuk meningkatkan standar mutu dan kualitasnya dalam menjawab beragam tantangan zaman, sekaligus peluang dan angin segar mendapatkan perlakuan yang sama dengan sekolah. Namun status ini justru menjadi masalah ketika institusi pendidikan berciri khas Islam yang sejak berdirinya telah dikelola oleh Kementerian Agama (Kemenag) ini belum mendapatkan perlakuan 'setara' atau belum sepenuhnya optimal dilayani oleh negara jika dibandingkan dengan pelayanan terhadap sekolah. Pada saat bersamaan, disadari atau tidak, status ini telah mendegradasi kekhasan tafaqquh fiddin madrasah akibat standarisasi kurikulum yang heavy kepada perangkat ilmu umum. Dengan kata lain, akibat pergeseran ini, madrasah pada kenyataannya tidak saja menjadikan lulusannya serba 'nanggung' antara mata pelajaran agama dan umum. Bahkan justru mengantarkan siswa madrasah meninggalkan orientasi tafaqquh fid din ke pola pikir yang serba profan dan materialistik. Secara sederhana, pada akhirnya modernisasi madrasah lebih mudah dipahami sebatas pengalihan konsentrasi peserta didik dan ketekunan mem- 
pelajari agama, menjadi kesungguhan mempelajari mata pelajaran umum.

Di titik ini, madrasah berada pada posisi dilematis, di mana muatan kurikulum distandarisasi melalui Standar Nasional Pendidikan(SNP) olehKemendikdasmenbud, tetapi aspek pengelolaan administratifnya berada di Kemenag. Meski demikian, perlahan tapi pasti, posisi dilematis tersebut mampu dijawab oleh madrasah. Kini madrasah telah berbenah dan mulai adaptif dengan SNP. Hal ini terbukti dari hasil penelitian Puslitbang Penda, Balitbang Kemenag tahun 2014 lalu tentang SNP Madrasah. Bahkan dalam berbagai aspek, tidak sedikit madrasah yang kualitasnya jauh lebih unggul dibandingkan sekolah, sebagaimana beberapa madrasah unggul yang telah disebutkan pada bab sebelumnya.

Permasalahan sejatinya terletak pada aspek administrasi pemerintahan yang nantinya berkaitan langsung dengan distribusi anggaran dan pemenuhan fasilitas infrastruktur madrasah. Berihwal dari Pasal 12 Ayat 1 Undang Undang Nomor 23 Tahun 2014 tentang Pemerintahan Daerah, klausul 'pendidikan' masuk dalam urusan konkuren yang berada pada lokus devolutif di pemerintah daerah (otonomi daerah) sebagaimana kewenangan pengelolaan sekolah. Padahal Madrasah yang dalam UU Sisdiknas sederajat dengan sekolah, tetap dikelola oleh Kemenag selaku institusi vertikal. Sementara pada Pasal 10 ayat 1 UU tersebut, terdapat klausul 'agama' sebagai urusan absolut (vertikal) yang diembankan kepada Kemenag. Lantas muncul pertanyaan, apakah madrasah masuk pada klausul 'pendidikan' dan seharusnya didesentralisasi ataukah ia masuk pada klausul 'agama' yang niscaya menjadi urusan absolut (pemerintah pusat)? Pada konteks inilah, penting mengemukakan beragam perspektif dalam perdebatan administrasi pemerintahan. Terdapat dua pola pendekatan dalam administrasi pemerintahan yang dapat dikemukakan di sini.

\section{Pendekatan Tekstual-Prosedural}

Jika didekati dari aspek tekstual ansich, maka madrasah masuk pada klausul 'pendidikan' yang menjadi urusan konkuren (desentralistik) dan sekaligus merupakan domain pemerintah daerah. Jika pun madrasah dikelola oleh Kemenag secara vertikal, maka argumentasi pertama ini membenarkan pula adanya keterputusan pembiayaan Dana Alokasi Umum (DAU) yang dikhususkan kepada pemerintah daerah di zona devolusi (Pemerintah Kabupaten/Kota) pada domain pendidikan kepada madrasah.

Inilah yang menjadi sebab utama problem terputusnya fasilitasi Pemda terhadap madrasah. Maknanya bahwa madrasah yang dikelola oleh Kemenag berada pada zona vertikal, bukan menjadi tanggung jawab Pemerintah Daerah di zona otonomi pendidikan. Perspektif pertama inilah yang selalu digunakan sebagai argumentasi menggeser madrasah menjadi urusan pemerintah daerah, sekaligus menjadi alasan untuk memosisikan madrasah sebagai 'anak tiri' dalam sistem pendidikan nasional.

\section{Pendekatan Holistik-Proporsional}

Ditinjau dari perspektif holistik-proporsional, dalam statusnya sebagai pendidikan formal yang sederajat dengan sekolah (umum), madrasah sebagai satuan pendidikan yang diikuti oleh peserta 
didik (warga negara), maka berlaku Pasal 1, 2, dan 3 pada UUD 1945, yakni bahwa: (1) setiap warga negara berhak mendapatkan pendidikan, (2) setiap warga negara wajib mengikuti pendidikan dasar dan pemerintah wajib membiayainya, (3) pemerintah mengusahakan dan menyelenggarakan satu sistem pendidikan nasional, yang meningkatkan keimanan dan ketakwaan serta akhlak mulia dalam rangka mencerdaskan kehidupan bangsa.

Sementara itu, sebagai subsistem pendidikan nasional, madrasah berhak mendapatkan perlakuan yang proporsional, adil, dan setara, baik di aspek perluasan akses, aspek peningkatan mutu dan daya saing, maupun aspek manajemen dan tata kelola, yang secara konstitusional dijamin oleh Pasal 31 ayat 4 UUD 1945, bahwa 'Negara memprioritaskan anggaran pendidikan sekurang kurangnya dua puluh persen dari anggaran pendapatan dan belanja negara serta dari anggaran pendapatan dan belanja daerah untuk memenuhi penyelenggaraan pendidikannasional'.Maknanya,penyebutan verbal numeral 20\% anggaran pendidikan harus dialokasikan secara merata kepada semua komponen sub sistem pendidikan, baik pada jenjang dan jenis pendidikan yang berbeda, dalam keseluruhan sistem pendidikan nasional, yang di dalamnya ada madrasah. Permasalahan terkait pembagian kewenangan pengelolaan, apakah akan dipilih secara vertikal maupun desentralistik dapat didudukkan pada aspek administratif pemerintahan (yang akan dikupas lebih lanjut dalam analisis ini), tidak boleh menggugurkan amanat dasar konstitusi tersebut. Jika tidak, berarti terjadi kesalahan konstitusional (constitutional failure).
Semangat pemerataan akses dalam konstitusi itulah yang selanjutnya menjadi landasan perumusan seluruh UU, termasuk keberadaan tiga UU yang terkorelasi secara substansial, yakni: UU Nomor 20 tahun 2003 tentang Sisdiknas, UU Nomor 23 Tahun 2014 tentang Pemerintahan Daerah dan UU Nomor 30 Tahun 2014 tentang Administrasi Pemerintahan.

Pertama, keberadaan UU Nomor 20 Tahun 2003 tentang Sisdiknas dalam konteks kesejajaran dan kesederajatan antara sekolah dan madrasah, musti dilihat maksud asli (original intent) perumusannya, di mana kesederajatan dan kesejajaran status madrasah terhadap sekolah sejatinya mengandung maksud untuk penyamaan perlakuan di semua aspeknya. Kedua, keberadaan UU Nomor 23 Tahun 2014 tentang Pemerintahan Daerah pada konteks pembagian antara urusan absolut dan urusan konkuren, di antaranya harus didasarkan pada prinsip eksternalitas dan kepentingan strategis secara nasional (Pasal 13 ayat 1). Dalam kajian ilmu administrasi pemerintahan, eksternalitas berarti unit pemerintahan yang terkena dampak langsung dari pelaksanaan suatu urusan pemerintahan, mempunyai kewenangan untuk mengurus urusan pemerintahan tersebut. Dari aspek ini, maka unit pemerintahan yang terkena dampak langsung dari penyelenggaraan pendidikan madrasah dengan segala kekhususannya, terutama menyangkut pembangunan mental-spiritual, adalah kementerian agama. Hal ini dapat ditelaah dari aspek historis dan sejarah panjang politik kebangsaan konteks pengelolaan madrasah. Pada posisi inilah, kementerian agama dapat diberikan kewenangan delegatif 
yang diberikan oleh pemerintah (presiden) melalui peraturan perundangan untuk mengelola urusan pendidikan madrasah. Pemberian kewenangan delegatif ini dapat mengacu pada Pasal 13 ayat 2 sampai ayat 5 UU Nomor 30 Tahun 2014 tentang Administrasi Pemerintahan, yang berbunyi: (2) Badan dan/atau Pejabat Pemerintahan memperoleh Wewenang melalui Delegasi apabila: (a) diberikan oleh Badan/ Pejabat Pemerintahan kepada Badan dan/ atau Pejabat Pemerintahan lainnya; (b) ditetapkan dalam Peraturan Pemerintah, Peraturan Presiden, dan/atau Peraturan Daerah; dan (c) merupakan Wewenang pelimpahan atau sebelumnya telah ada. (3) Kewenangan yang didelegasikan kepada Badan dan/atau Pejabat Pemerintahan tidak dapat didelegasikan lebih lanjut, kecuali ditentukan lain dalam peraturan perundang-undangan. (4) Dalam hal ketentuan peraturan perundang-undangan menentukan lain sebagaimana dimaksud pada ayat (3), Badan dan/atau Pejabat Pemerintahan yang memperoleh Wewenang melalui Delegasi sebagaimana dimaksud pada ayat (2) dapat mensubdelegasikan Tindakan kepada Badan dan/atau Pejabat Pemerintahan lain dengan ketentuan: (a) dituangkan dalam bentuk peraturan sebelum Wewenang dilaksanakan; (b) dilakukan dalam lingkungan pemerintahan itu sendiri; dan (c) paling banyak diberikan kepada Badan dan/atau Pejabat Pemerintahan 1 (satu) tingkat di bawahnya. (5) Badan dan/ atau Pejabat Pemerintahan yang memberikan Delegasi dapat menggunakan sendiri Wewenang yang telah diberikan melalui Delegasi, kecuali ditentukan lain dalam ketentuan peraturan perundangundangan.
Lebih jauh, secara konseptual maupun praktis, pembagian urusan antara pemerintah pusat dengan pemerintah daerah harus pula dilihat sebagai bagian tak terpisahkan dari proses politik. Konteks pelimpahan kewenangan pengelolaan pendidikan madrasah kepada Kementerian agama sesungguhnya secara existing telah terjadi semenjak awal berdirinya NKRI, dan selama diberikan garis batas penyelenggaraan pemerintahan dan kewenangan pengelolaannya, maka dalam disiplin administrasi negara, hal ini boleh dilakukan.

Pelimpahan kewenangan urusan pendidikan madrasah secara delegatif oleh Presiden ini dilegitimasi oleh Peraturan Pemerintah (PP) Nomor 66 Tahun 2010 sebagai revisi dari PP Nomor 17 Tahun 2010, terutama pada Pasal 1 ayat 9, ayat 11 dan ayat 14 dalam mendefinisikan Madrasah Ibtidaiyah (MI), Madrasah Tsanawiyah (MTs), dan Madrasah Aliyah (MA), sebagai: salah satu bentuk satuan pendidikan formal dalam binaan Menteri Agama yang menyelenggarakan pendidikan umum dengan kekhasan agama Islam pada jenjang pendidikan masing-masing. Yang harus digarisbawahi adalah kata "pendidikan formal dalam binaan Menteri Agama” secara tegas mendelegasikan urusan pendidikan formal madrasah kepada Kementerian agama. Kewenangan delegatif ini dipertegas pada Pasal 53B ayat 3 secara tegas memberikan kewenangan kepada menteri agama untuk membuat Peraturan Menteri Agama yang khusus mengatur pengelolaan dan penyelenggaraan pendidikan madrasah.

Dari keseluruhan hierarki peraturan perundangan, sejak dari UUD 1945 hingga peraturan pemerintah, memberikan kewenangan pengelolaan madrasah di 
bawah instansi vertikal kementerian agama. Dengan demikian, tarik ulur klausul 'pendidikan' dan klausul 'agama' pada kontekspembagiankewenanganpengelolaan madrasah merupakan hak presiden untuk memberikan kewenangan delegatifnya kepada kementerian di bawahnya, dengan ketentuan dan batasan yang jelas, dengan mempertimbangkan aspek aspek historis, politik dan yuridis. Dengan demikian, dapat dikatakan bahwa perspektif holistikproporsional dengan berbagai legitimasi hukum dan administrasinya, pengelolaan pendidikan madrasah tetap niscaya dikelola oleh Kementerian Agama.

\section{Peningkatan Anggaran Pendidikan Madrasah}

Pada bagian subbab sebelumnya telah dijelaskan bahwa secara hierarkis, konstitusi dan peraturan perundangan di bawahnya mengamanatkan pemberian hak pendidikan di aspek perluasan akses, aspek peningkatan mutu dan daya saing, maupun aspek manajemen dan tata kelola secara merata, tidak terkecuali antara madrasah maupun sekolah (umum).

Madrasah sebagai kewenangan yang pengelolaannya didelegasikan oleh pemerintah (Presiden) kepada Kementerian Agama, juga sepatutnya mendapatkan porsi anggaran $20 \%$ secara seimbang berbasis unit cost penyelenggaraan pendidikan. Hal ini karena madrasah mempunyai kontribusi besar bagi perkembangan dan peningkatan mutu pendidikan nasional. Setidaknya dapat dilihat dari beberapa fakta berikut:

Pertama, pada aspek kepeminatan masyarakat terhadap madrasah. Fakta yang tidak dapat dimungkiri bahwa terjadi lonjakan kepeminatan masyarakat terhadap madrasah yang setiap tahunnya naik. Sejak tahun 2010 hingga tahun 2013 jumlah siswa pada MI, MTs dan MA terus meningkat dengan rata-rata peningkatan mencapai 3,7\% per tahun (lihat Tabel di bawah).

Tabel 1. Perkembangan Jumlah Siswa Madrasah tahun 2010 - 2013

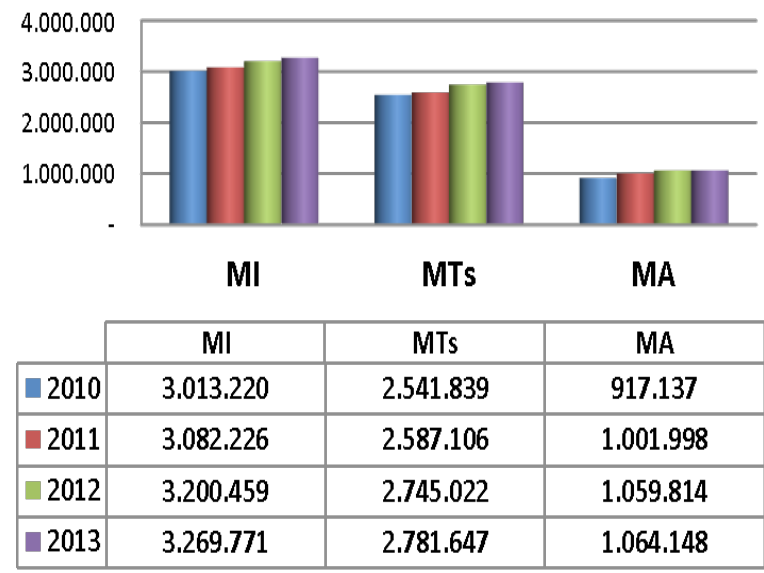

Kedua, kontribusi madrasah terhadap peningkatan APK Nasional. Kontribusi Pendidikan Madrasah terhadap peningkatan Angka Partisipasi Kasar Pendidikan Nasional dalam 4 tahun terakhir mengalami peningkatan rata-rata 4,2\% (lihat tabel di bawah)

Tabel 2. APK Nasional Madrasah

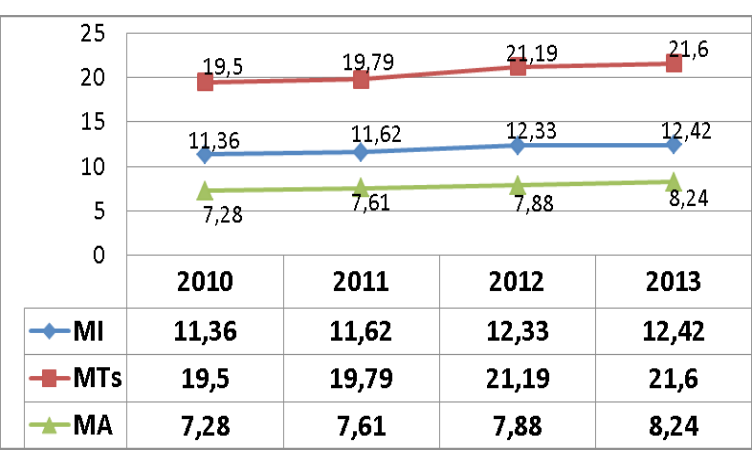

Ketiga, harus diakui bahwa 91,6\% dari keseluruhan madrasah adalah berstatus swasta. Dan dalam skala mayoritas, madrasah swasta masih dalam kondisi mem- 
prihatinkan, akibat kebijakan alokasi anggaran pendidikan oleh negara kepada madrasah yang masih 'belum proporsional'. Sejatinya, mayoritas madrasah swasta yang masih membutuhkan peningkatan di aspek perluasan akses, peningkatan mutu dan daya saing serta tata kelola, akan mampu teratasi jika negara hadir mengatasi masalah tersebut. Karena kecilnya anggaran jika dibandingkan dengan kebutuhan yang harus dipenuhi, Kementerian Agama belum mampu hadir secara proporsional mengatasi permasalahan tersebut. Terutama kebutuhan madrasah di wilayah perbatasan negara dan di daerah minoritas muslim.

Keempat, mengingat anggaran pendidikan yang disediakan dalam APBN yang dialokasikan melalui belanja pemerintah pusat dan transfer daerah meningkat signifikan dari $\mathrm{Rp} 76,7$ triliun pada tahun 2005 menjadi Rp 368,9 triliun pada tahun 2014. Namun demikian, anggaran pendidikan yang disediakan dalam APBN untuk Program Pendidikan Islam rata-rata sebesar hanya $11 \%$ dari total anggaran pendidikan tersebut, yang harus dibagi menjadi anggaran madrasah, pendidikan agama dan keagamaan serta pendidikan tinggi agama. Sementara anggaran pendidikan yang dikelola oleh Kemdikbud adalah sebesar 21,6\%. Padahal, sekali lagi, amanat konstitusi memerintahkan negara untuk memberikan pelayanan pendidikan di semua aspek secara merata, adil dan proporsional. Lebih lanjut, total $11 \%$ anggaran pendidikan Islam yang dikelola oleh Kemenag, tentu masih jauh dari porsi yang dimandatkan konstitusi (20\% anggaran pendidikan). Implikasi dari keterbatasan anggaran tersebut, sebagaimana penelitian yang dilakukan oleh Puslitbang Pendidikan
Agama dan Keagamaan tentang unit cost pendidikan madrasah tahun 2011 menunjukkan bahwa 70\% madrasah swasta menggunakan dana bantuan operasional sekolah (BOS) tidak sesuai peruntukannya, melainkan digunakan untuk pembiayaan gaji guru yayasan.

Atas dasar berbagai fakta di atas, maka seharusnya pemerintah memberikan porsi anggaran yang proporsional sesuai dengan amanat konstitusi. Oleh karena itu, anggaran pendidikan madrasah di kementerian agama seharusnya ditingkatkan sesuai porsinya (20\%). Adapun penambahan anggaran pendidikan madrasah secara operasional dapat dilakukan melalui mekanisme dekonsentrasi (kantor wilayah kementerian agama yang berkedudukan di provinsi sebagai wakil pemerintah pusat di daerah). Hal ini serupa dengan pola penganggaran untuk sekolah melalui dana transfer daerah pada kabupaten/kota.

\section{Perluasan Struktur Pengelola Pendidikan Madrasah di Kementerian Agama}

Eksistensi madrasah telah mengalami transformasi secara gradual. Dilihat dari aspek konstruksi kebijakan perundangan, penyelenggaraan madrasah sebagai satuan pendidikan formal semakin kokoh, UndangUndang Nomor 20 Tahun 2003 tentang Sistem Pendidikan Nasional telah menegaskan bahwa madrasah dan sekolah memiliki kedudukan yang sama. ${ }^{2}$ Lebih jauh, madrasah

${ }^{2}$ Undang-Undang No. 20 Tahun 2003, pasal 17 ayat (2), Pendidikan Dasar berbentuk Sekolah Dasar (SD) dan Madrasah Ibtidaiyah (MI) atau bentuk lain yang sederajat serta Sekolah Menengah Pertama (SMP) dan Madrasah Tsanawiyah (MTs), atau bentuk lain yang sederajat. Pasal 18 ayat (3), Pendidikan menengah berbentuk Sekolah Menengah Atas (SMA), 
sebagai satuan pendidikan diharapkan menjadi lembaga pendidikan plus yang memiliki posisi strategis dengan berbagai keunggulan, baik dalam aspek penguatan agama dan akhlak mulia serta penguasaan sains dan pelajaran umum lainnya. Peraturan Menteri Agama (PMA) Nomor 90 Tahun 2013 tentang Penyelenggaraan Pendidikan Madrasah, pada Pasal 1 menyebutkan bahwa madrasah merupakan satuan pendidikan formal dalam binaan menteri agama yang menyelenggarakan pendidikan umum dan kejuruan dengan kekhasan agama Islam yang mencakup Raudlatul Athfal, Madrasah Ibtidaiyah, Madrasah Tsanawiyah, Madrasah Aliyah dan Madrasah Aliyah Kejuruan.

Penjelasan di atas, menegaskan bahwa keberadaan madrasah yang semula eksistensinya sangat lemah, kini semakin kuat dalam sistem pendidikan nasional. Semakin menguatnya eksistensi madrasah tidak dapat dipisahkan dari peran aktif Kementerian Agama yang telah memberikan pembinaan dalam pengelolaan dan penyelenggaraan pendidikan di madrasah secara sistematik dan berkesinambungan, baik aspek perluasan dan pemerataan akses, peningkatan mutu, relevansi dan daya saing.

Sebagai upaya peningkatan aksesibilitas dan kualitas pendidikan madrasah, peran Kementerian Agama tidak hanya sebatas memberikan bantuan dan pembinaan, namun juga melalui strategi penguatan kelembagaan madrasah dengan dukungan sistem manajemen dan tata kelola yang efektif, efisien dan akuntabel. Penguatan sistem organisasi, regulasi, sumber

Madrasah Aliyah (MA), Sekolah Menengah Kejuruan (SMK), dan Madrasah Aliyah Kejuruan (MAK), atau bentuk lain yang sederajat. daya manusia, monitoring dan evaluasi, pengelolaan data dan informasi, penjaminan mutu pendidikan, serta pencitraan yang baik merupakan perwujudan dari strategi kebijakan pengembangan madrasah, termasuk di antaranya pengembangan status kelembagaan melalui program penegerian madrasah swasta yang dikelola oleh masyarakat ${ }^{3}$. Penegerian madrasah-madrasah swasta merupakan pengejawantahan kebijakan pemerintah yang bersungguh-sungguh memperhatikan perluasan akses dan peningkatan mutu pendidikan. ${ }^{4}$ Perubahan status "Negeri" pada madrasah swasta, di satu sisi akan menguatkan kelembagaan satuan pendidikan tersebut dan meningkatkan daya saing madrasah. ${ }^{5}$ Porsi pengelolaan yang lebih besar oleh pemerintah (Kementerian agama) akan berkonsekuensi terhadap peningkatan kapasitas pengelola pendidikan madrasah.

3 Peraturan Menteri Agama No. 14 Tahun 2014 tentang Pendirian Madrasah yang dilakukan oleh Pemerintah dan Penegerian Madrasah yang dilakukan oleh Masyarakat. PMA ini menggariskan proses penegerian madrasah oleh Menteri Agama setelah mendapatkan persetujuan dari Menteri yang membidangi urusan Pendayagunaan Aparatur Negara.

${ }^{4}$ Keputusan Menteri Agama (KMA) No. 47 tahun 2009, bahwa dalam rangka meningkatkan mutu pendidikan Madrasah Ibtidaiyah Swasta sebagai salah satu jalur pendidikan dalam Sistem Pendidikan Nasional, perlu menetapkan KMA tentang Penetapan 46 Madrasah Ibtidaiyah Negeri.

${ }^{5}$ Hasil penelitian Evaluasi Penegerian Madrasah, Puslitbang Pendidikan Agama dan Keagamaan tahun 2014, menunjukkan bahwa program penegerian madrasah Kementerian Agama secara umum berhasil mendongkrak citra madrasah dan meningkatkan peran serta masyarakat, hal ini dipengaruhi persepsi masyarakat terhadap mutu satuan pendidikan "Negeri" dibandingkan madrasah swasta atau bahkan sekolah swasta. 
Secara administratif, Kementerian Agama merupakan institusi yang memiliki pola kewenangan kebijakan vertikal (vertical authority of policy) termasuk dalam hal pengelolaan madrasah. Jumlah madrasah di seluruh Indonesia sebanyak 44.979, sedangkan yang berstatus negeri sejumlah 3881 madrasah, terdiri dari Madrasah Ibtidaiyah Negeri (1686) lembaga, Madrasah Tsanawiyah Negeri (1437) lembaga, dan Madrasah Aliyah Negeri (758) lembaga, selebihnya merupakan madrasah swasta.

Tabel: 3. Madrasah Negeri dan Swasta di Indonesia ${ }^{6}$

\begin{tabular}{|r|l|r|r|r|r|}
\hline \multirow{2}{*}{ No } & \multirow{2}{*}{ Madrasah } & \multicolumn{4}{|c|}{ Status } \\
\cline { 3 - 6 } & & Negeri & \multicolumn{1}{c|}{$\%$} & \multicolumn{1}{c|}{ Swasta } & \multicolumn{1}{c|}{$\%$} \\
\hline 1 & Ibtidaiyah & 1686 & 43,4 & 21385 & 52,0 \\
\hline 2 & Tsanawiyah & 1437 & 37,0 & 13807 & 33,6 \\
\hline 3 & Aliyah & 758 & 19,5 & 5906 & 14,4 \\
\hline & Jumlah & 3881 & 100 & 41098 & 100 \\
\hline
\end{tabular}

Struktur pengelolapendidikanmadrasah saat ini belum memadai, mengingat besarnya jumlah madrasah di Indonesia hanya dikelola oleh direktorat pendidikan madrasah (unit eselon II), di tingkat Provinsi dikelola oleh bidang pendidikan madrasah (eselon III), dan di tingkat Kabupaten/Kota dikelola oleh Kepala seksi (eselon IV). Hal ini tentu tidak sebanding antara ruang lingkup pengelolaan dan tanggung jawab pembinaan yang besar, dibandingkan dengan struktur organisasi yang dimiliki.

Oleh karena itu, semestinya dilakukan peningkatan kewenangan dan perluasan struktur organisasi pengelola pendidikan madrasah, dari level Direktorat Pendidikan Madrasah menjadi Direktorat Jenderal Pendidikan Madrasah. Hal ini menjadi konsekuensi dari peran pemerintah dalam rangka memberikan pelayanan pendidikan yang optimal kepada masyarakat, terutama pendidikan madrasah dibawah pengelolaan kementerian agama.

\section{PENUTUP}

Kewenangan pengelolaan pendidikan madrasah dalam perspektif administrasi pemerintahan menunjukkan, bahwa pengelolaan pendidikan madrasah merupakan domain pemerintah dan secara delegatif telah diberikan oleh pemerintah kepada Kementerian Agama.

Anggaran penyelenggaraan pendidikan madrasah belum memenuhi dua puluh persen dari Anggaran Pendapatan dan Belanja Negara (APBN) serta dari Anggaran Pendapatan dan Belanja Daerah (APBD) sebagaimana dimandatkan konstitusi. Penganggaran yang belum proporsional ini telah berdampak terhadap penyelenggaraan madrasah yang tidak optimal.

Organisasi pengelola pendidikan madrasah di lingkungan Kementerian Agama belum optimal dalam melayani penyelenggaraan pendidikan madrasah. Peningkatan wewenang dan perluasan struktur organisasi pengelola pendidikan madrasah merupakan kebutuhan mendesak dalam rangka menyeimbangkan antara ruang lingkup pembinaan dan kapasitas organisasi.

6 Buku Statistik Pendidikan Islam Tahun Pelajaran 2011/2012, Direktorat Jenderal Pendidikan Islam Kementerian Agama. 


\section{SARAN-SARAN}

1. Pemerintah perlu menegaskan bahwa pengelolaan Pendidikan Madrasah merupakan kewenangan pemerintah dalam binaan Kementerian Agama. Penegasan tersebut sebaiknya dituangkan dalam Peraturan Pemerintah tentang Pengelolaan Pendidikan Madrasah.

2. Pemerintah dipandang perlu untuk memenuhi anggaran pendidikan madrasah secara proporsional, sebagaimana dimandatkan oleh konstitusi. Mekanisme penambahan alokasi anggaran bagi pendidikan madrasah dapat dilakukan melalui pola dekonsentrasi.

3. Pemerintah perlu merespons beban kerja pengelolaan madrasah dengan meningkatkan kewenangan dan perluasan struktur organisasi pengelola pendidikan madrasah dari level Direktorat Pendidikan Madrasah menjadi Direktorat Jenderal Pendidikan Madrasah.

\section{SUMBER BACAAN}

Hoessein, Bhenyamin (2002): "Kebijakan Desentralisasi" Makalah dalam Seminar Setahun Implementasi Kebijakan Otonomi Daerah di indonesia diselenggarakan oleh Program Studi Ilmu politik. Pascasarjana UGM,

Hoessein,Bhenyamin(2003):"Penyempurnaan UU No. 22 Tahun 1999 Menurut Konsepsi Otonomi Daerah Hasil Amandemen UUD 1945," Makalah dalam Seminar dan Lokakarya Pembangunan Hukum Nasional VIII. Badan Pembinaan Hukum Nasional - Departemen Kehakiman dan Hak Asasi Manusia, 14-18 Juli, Denpasar-Bali.

Kelsen, Hans (1973): General Theory of Law and State, Translated by Anders Wedberg; copyright renewed. New York: Russel and Russel,

Koswara (2001): Otonomi Daerah untuk Demokrasi dan Kemandirian Rakyat. Jakarta, Yayasan PARIBA

Maksum (1999): Madrasah; Sejarah dan Perkembangannya. Jakarta, Logos Wacana Ilmu,

Mawhood. P. (1983): Local Government in the Third World: The Experience of Tropical Africa. Chichester: John Wiley \&Sons.

Pide (1999): Otonomi Daerah dan Kepala Daerah Menurut UUD 1945. Jakarta, Pustaka Harapan

Richard. A Musgrave \& Peggy B. Musgrave (1989): Public Finance in Theory and Practice. Edition, NewYork, london, Mc. Graw Hill,

Sarundajang (2002): Arus Balik Kekuasaan Pusat ke Daerah. Jakarta, Pustaka Sinar Harapan.

Sodjuangon Situmorang (2002): Model Pembagian Urusan Pemerintahan antara 
Pemerintah, Propinsi, dan Kabupaten/Kota. Jakarta, Universitas Indonesia.

Suwandi (1999): Format Otonomi Daerah Propinsi dan Kabupaten atau Kota Berdasarkan UU 22 Tahun 1999 dan UU 25 Tahun 1999. makalah, Jakarta.

The Liang Gie (1968): Pertumbuhan pemerintahan Daerah di Negara Republik Indonesia. Jakarta, Gunung Agung, Jilid I,

Tjokroamidjoyo, Bintoro (1995): Pengantar Administrasi Pembangunan. Jakarta, Pustaka LP3ES

Badan Litbang dan Diklat, Kementerian Agama, Respons Masyarakat terhadap Jatidiri Madrasah, Tahun 2007.

Badan Litbang dan Diklat, Kementerian Agama, Studi Pembiayaan Pendidikan Madrasah, Tahun 2011.
Badan Litbang dan Diklat, Kementerian Agama, Keberhasilan Pembelajaran Pendidikan Agama Islam di Madrasah, Tahun 2012.

Badan Litbang dan Diklat, Kementerian Agama, Studi Kebutuhan Akreditasi Madrasah, Tahun 2013.

Badan Litbang dan Diklat, Kementerian Agama, Evaluasi Penegerian Madrasah, Tahun 2014.

Badan Litbang dan Diklat, Kementerian Agama, Madrasah di Daerah Marginal, Tahun 2014. 